\title{
AN ALTERNATIVE TO THE BATTLE OF EXPERTS: HOSPITAL EXAMINATION OF CRIMINAL DEFENDANTS BEFORE TRIAL
}

\author{
HENRY WeIHOFEN*
}

It is fairly clear that improvement in the criminal law governing insanity as a defense must come-and indeed is coming-not through revision of the substantive law on the subject, but through improvement in the procedure for handling these cases.

It is true that most of the debate on the subject has centered around the substantive law governing the "tests" of criminal responsibility: what sort and degree of mental disorder must a person have to excuse him from criminal liability for his act? The sad fact is, however, that all that has been said and written on that subject during the past hundred years has resulted in just exactly nothing so far as affecting any change in the law is concerned. The tests of insanity have not been changed in the slightest; even M'Naghten's Case, ${ }^{1}$ usually looked upon as the leading case on the subject, added nothing to the law as it stood before that famous opinion was delivered in 1843 . As the writer has pointed out elsewhere, ${ }^{2}$ there has not even been any tendency toward a change, and the possibility of any reform in this direction in the near future seems slight.

This lack of any development in the substantive law of criminal responsibility has been the subject of so much deploring and caustic comment that we have rather lost sight of the very real advances that have been made by means of procedural changes. It is the purpose of this paper to discuss one of the most helpful of the modern procedural devices which have been found for improving the handling of these cases-that embodied in statutes providing for a psychiatric examination of the defendant before the criminal trial.

\section{OUR INEXPERT USE OF EXPERTS}

If our jury system does require that the question of the defendant's mental responsibility be diagnosed by a jury whose only qualification for that complex

- Ph.B., 1926, J.D., I928, J.S.D., 1928, University of Chicago. Member of the Illinois Bar. Instructor In Law, University of Colorado School of Law. Conducted research in criminal law of insanity for Commonwealth Fund, 1928-30. Member of the Committee on Survey of Crime, Criminal Law, and Criminal Procedure of the Association of American Law Schools. Author of Insanity as a Defense in Criminal Law (1933). Contributor to legal periodicals.

1 10 Clark \& Fin. 200 (1843).

2 Wethopen, Insanity as a Defense in Criminat Law (1933) 64-68. 
scientific task is that they are good men and true, we ought at least to give them a little more assistance in that duty than we now give. It is true that to aid the jury we permit expert testimony on the issue to be introduced. However, the method of presenting this expert testimony in most states is open to serious criticism. To mention only the defects most commonly pointed out:

r. Any reputable practicing physician is legally qualified to speak as an expert on insanity, even though he may never have had any instruction or experience in mental disease. As a result, it is usually possible to hunt up some quacks or eccentric "experts" whose fantastic theories will permit them to testify as counsel wishes, even though no reputable pychiatrist would agree with them. The jury is usually unable to distinguish the competent expert from the incompetent, and obviously has no means of knowing how many experts refused to testify as counsel wished, before acceptable experts were found. The law relies upon cross-examination to reveal the witness' incompetency or inaccuracy, but as a matter of fact it is often the witness whose judgment is unobscured by too much knowledge of the subject who will be most positive in his assertions and who will make the best impression on the jury. Furthermore, leaving the witness' qualifications to be brought out on cross-examination too often leads to the sort of badgering and bickering for which these cases have become notorious.

2. The partisan nature of the expert's services makes it difficult to obtain reliable and unbiased evidence. Allowing experts in criminal trials to be called on behalf of the parties is peculiar to the common law. ${ }^{3}$ It lies at the root of one of the great evils of which such trials are productive-lack of that impartiality which should be characteristic of scientific inquiry.

3. The opinion testified to is often not based upon sufficient scientific observation and examination. At best, an examination made while the subject is in prison is not very satisfactory, and often no really thorough physical, mental, and neurological examination or study of the case history is even attempted, the witness' opinion being based merely upon what the defendant chooses to tell about himself or what his family tells about him. Worse yet, an expert who has not examined or even seen the defendant at all is competent to testify in answer to hypothetical questions. ${ }^{4}$ Such questions may include only such facts, proved or hoped to be proved, as tend to support the questioner's side of the case. ${ }^{5}$ Moreover, the witness may not himself believe in the truth of the facts assumed. ${ }^{6}$ The unfairness and unsoundness of the use of hypothetical questions in these cases has been pointed out by alienists repeatedly.

\footnotetext{
s For a discussion of the rôle of the expert in continental criminal procedure, see Ploscowe, The Expert Witness in Criminal Cases in France, Germany, and ltaly, infra, p. 504.

"Parrish v. State, 139 Ala. 16, 36 So. 1012 (1903).

Pcople v. Truck, 170 N. Y. 203,63 N. E. 28I (r902), and cases cited in WEIHoren, op. cir. supra note 2, at 208.

- Ryan v. People, 50 Colo. 99, I I4 Pac. 306 (Igri).

${ }^{7}$ Dr. L. Vernon Briggs has condemned the hypothetical question as misleading, unfair, an excrescence
} 
The Solution: Commiment to the State Hospital for Examination

The solution which a growing number of states have found for this situation is a comparatively simple one. They have enacted statutes which provide that whenever the defendant's sanity or mental condition becomes an issue in a criminal case, the court shall commit the defendant to a state mental institution for observation and examination. Usually the period of such commitment is limited to thirty days. At the end of that time, the superintendent of the hospital reports his findings, and may testify as an impartial witness in the case.

There is certainly nothing revolutionary in such a provision. It can't even be called new, for the state of Maine has had a statute of this sort for almost ninety years. There is only one reason for calling attention to these statutes, and that is the remarkable degree of success they have had in eliminating the objectionable features attaching to insanity trials in most of the states. They have practically rendered extinct the disgraceful "battles of the experts" which still characterize insanity cases elsewhere, and have substituted an impartial, scientific diagnosis of the defendant's mental condition for the theatrical spectacle of a court trial.

The Maine statute refers only to the issue of insanity as a defense, i.e., was the accused, at the time of the offense charged, so mentally disordered as to be criminally irresponsible. ${ }^{8}$ Five states, Maryland, Massachusetts, New Hampshire, New York, and Wisconsin, have statutes providing for commitment to a state hospital for observation to determine the question of the defendant's mental capacity to stand trial, i.e., whether he is rational enough to understand the nature of the proceedings and to aid in his own defense. ${ }^{9}$ In three states, Colorado, Ohio, and Vermont, the statutes cover both situations, and provide that whenever the question of insanity arises, either as a defense or as a reason for the defendant's not being presently tried, the court may commit him to a state hospital for observation. ${ }^{10}$

In theory, these two issues are entirely different. The first involves the question of the defendant's guilt or innocence: was he, at the time of the act charged, so mentally disordered as not to know that it was wrongful, or, in some seventeen states, if he did know that the act was wrongful, was he mentally incapable of resisting the impulse to commit it? If so, he is not responsible for his act, and should be

and a disgrace to the law, and a travesty on justice. Briggs, Medico-Legal Insanity and the Hypothetical Question (1923) I4 J. CRIM. L. \& CRImin. 62, 72. Dr. Wm. A. White, one of the most eminent psychiatrists in the country, has said that "in a large experience I have never known a hypothetical question, in a trial involving the mental condition of the defendant, which in my opinion offered a fair presentation of the case." White, Insanity and the Criminal Law (I923) 56. The American Psychiatric Association and the New York Psychiatric Society have urged the abolition of the hypothetical question. Briggs, supra, at 74; Menninger, Medicolegal Proposals of the American Psychiatric Association (1929) 19 J. CrIM. L. \& CRIM. $367,376$.

${ }^{8}$ Me. Rev. Stit. (I930) c. I49, \$I; Me. Pub. Laws I933, c. I, \$4I6.

-Mo. Ann. Code (Bagby, I924) art. 59, $\$ 8$, ro (examination made by" Board of Mental Hygiene); Mass. Ann. Laws (Michie, I933) c. 123, \$100; N. H. Pub. Laws (1926) c. I1, \$13; N. Y. Code Crims. Proc. $\S 836$, as amended, N. Y. Laws I933, c. 564; WIs. StAT. (I933) $\$ 357.12$ (3).

${ }^{20}$ Colo. Laws 1927, c. 90, \$2; Ohio AN. Code (Page, 1932) \$13441-4; Vt. Gen. LAws (1917) $\$ \$ 2602,2620$. 
found not guilty by reason of insanity. The other does not ga to the question of guilt or innocence at all, but only to the defendant's present mental condition, under the principle that the law will not try or execute a person while he is too insane to understand what is happening to him, or to state rationally whatever he may have to say in his own defense.

In application, however, this distinction becomes less clear, because a person suffering from a serious psychosis will often be found to be too disordered to meet either test, whether of responsibility for his act, or present ability to stand trial. Nevertheless, it is true that they cover fundamentally different aspects of the case, and we shall examine particularly the statutes permitting hospital observation for the purpose of determining the question of criminal responsibility at the time of the act charged, since that involves the ultimate question of guilt or innocence.

\section{Experience Under the Colorado Statute}

The Colorado law is typical of all four of the state statutes permitting commitment for this purpose, and provides a good subject for study, because it has been very frequently resorted to since its enactment in 1927 , and there are complete statistics available.

In form, the Colorado law is simple. The provision we are interested in is embodied in one sentence, which reads:

"Upon the making of any such plea of insanity, the judge shall forthwith commit the defendant to the Colorado Psychopathic Hospital at Denver or to the State Hospital at Pueblo where the defendant shall remain under observation for such time as the court may direct, not exceeding one month."11

On arriving at the'hospital, the patient is assigned to particular staff physicians for examination. The case is then presented at staff meeting, and the whole staff passes on the mental condition of the patient. Frequently, the patient appears before the staff meetings several different times, so that an accurate estimate of his condition can be obtained. When the staff has studied the patient sufficiently to make a diagnosis, the superintendent makes his report to the court. When the case is tried, the superintendent is usually subpoenaed to testify to his finding. In some cases, other members of the staff are also subpoenaed.

The remarkable fact is that in the comparatively few years that the law has been on the books, its soundness has so demonstrated itself that today lawyers for the defense rarely if ever contest the finding of the hospital. If, on the plea of insanity and after commitment, the hospital reports that the man is sane and responsible, counsel almost invariably accept that finding, and drop the insanity defense. This means that the only evidence on that issue is that of the hospital staff members. There is no battle of experts to make a farce of the judicial process and to confuse the jury. As a result, the jury, with rare and understandable exceptions, renders a verdict in accordance with the hospital's findings.

"Colo. Laws 1927, c. 90, \$2. 
The superintendents of the Colorado state hospitals have adopted the practice, in their reports to the courts, of making not merely a formal finding of "sane" or "insane," but also recommendations as to the proper disposition of the defendant. Among their recommendations, the hospitals have not hesitated to include such suggestions as "institutionalization" and "psychiatric supervision" for cases requiring individualization, even though stating in the report that it was realized there were no facilities in the state for carrying out these recommendations. In this way, the hospitals have been able to do much to educate judges, prosecutors, and lawyers in the need for specialized treatment for certain types of disordered offenders.

The operation of the law can perhaps best be appreciated after consulting the records. During the eight years the law has been in effect, from Aug. I, 1927 to July 30, I935, there have been 2Ir commitments for observation to the Psychopathic Hospital, and 42 to the State Hospital. Of this total of 253 , 153 , or more than 60 per cent, were found sane; 97, or slightly less than 39 per cent, were found insane; one recovered while in the hospital and one was still in the hospital undiagnosed. But these are merely rough totals. A more complete analysis of the cases committed to the Psychopathic Hospital is given below:

Colorado Psychopathic Hospital

Cases Admitted Under 1927 Law from August 27, r927 to July 30, 1935

Total rg27 Law Cases ......................................... 211

Formal Opinion as returned to the Court:

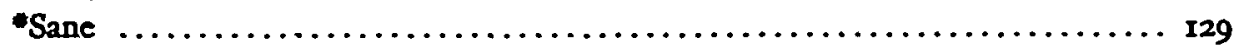

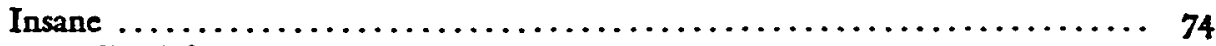

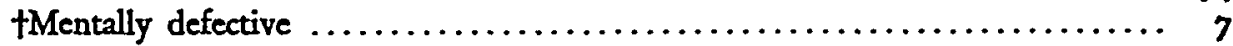

Still in hospital, opinion not given $\ldots \ldots \ldots \ldots \ldots \ldots \ldots \ldots \ldots \ldots \ldots \ldots \ldots \ldots \ldots$ I

Recommendations of the Hospital as to Future Care:

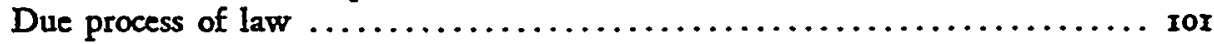

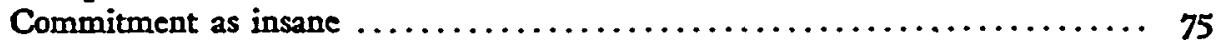

Suspended sentence with psychiatric follow-up $\ldots \ldots \ldots \ldots \ldots \ldots \ldots \ldots \ldots$ is

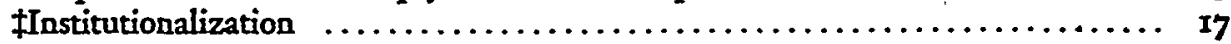

Commitment to training school for mental defectives $\ldots \ldots \ldots \ldots \ldots \ldots \ldots \ldots$ 2

Still in hospital, no recommendations made ...................... I

Action of the Court:

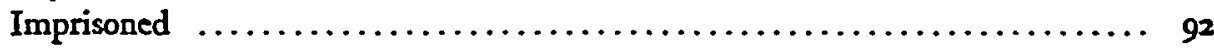

Committed as insane $\ldots \ldots \ldots \ldots \ldots \ldots \ldots \ldots \ldots \ldots \ldots \ldots \ldots \ldots \ldots \ldots \ldots \ldots, 6_{7}$

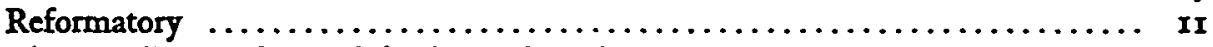

Charges dismissed and defendant released $\ldots \ldots \ldots \ldots \ldots \ldots \ldots \ldots \ldots \ldots, \quad 9$

On probation $\ldots \ldots \ldots \ldots \ldots \ldots \ldots \ldots \ldots \ldots \ldots \ldots \ldots \ldots \ldots \ldots \ldots \ldots \ldots, 8$

- This figure ineludes those cases of mental deficiency where the patient was considered to be responsible for his acts.

tIn these cases the mental defect was so great that the patient was not considered responsible for his acts and institutionalization was recommended, although the mental deficiency was not accompanied by a peychosis.

\pm Recommended in cases not legally insane, with the period of confinement dependent upon the individual rather than the crime committed. 
Disposition unknown to the hospital as yet $\ldots \ldots \ldots \ldots \ldots \ldots \ldots \ldots \ldots, 7$

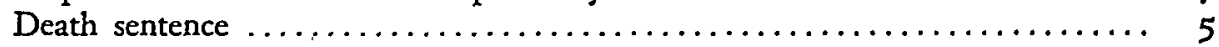

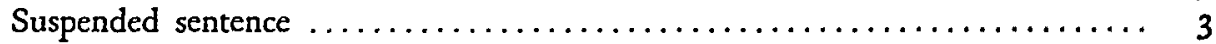

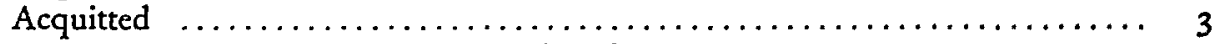

Committed to State Home for Mental Defectives $\ldots \ldots \ldots \ldots \ldots \ldots \ldots \ldots$ I

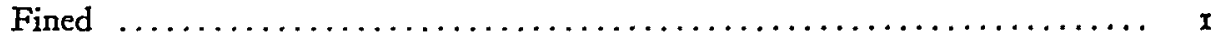

State Industrial School following violation of parole $\ldots \ldots \ldots \ldots \ldots \ldots \ldots \ldots$ I

Reformatory following violation of parole $\ldots \ldots \ldots \ldots \ldots \ldots \ldots \ldots \ldots \ldots$ I

Penitentiary following violation of parole $\ldots \ldots \ldots \ldots \ldots \ldots \ldots \ldots \ldots \ldots \ldots$ I

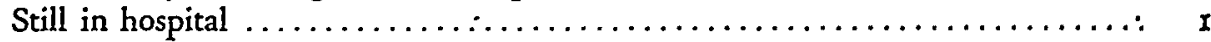

During the same period, some 42 more patients were committed to the State Hospital at Pueblo. Because this number is comparatively small, and because no similar statistics have been published regarding the operation of these laws in any state, it may be useful to list the history of each of these cases. The results obtained are typical. Indeed, if anything, they rather understate the efficiency of the law, because, as can be seen below, in five cases out of 42 , the jury refused to follow the recommendation of the hospital. This is a much higher percentage of error (in so far as we can assume that the hospital is always right in its diagnosis and the jury, if it disagrees, wrong) than found in any other state having a similar provision, or at the Psychopathic Hospital at Denver, under the same law. Yet reference to the peculiar facts of these five cases shows that there were, in every one of them, other considerations which influenced the jury.

\section{Colorado State Hospital}

Cases Admitted under 1927 Law from August I, 1927, to July 30, 935

\begin{tabular}{|c|c|c|c|c|c|c|}
\hline Name & Age & Offense & Diagnosis & $\begin{array}{l}\text { Recommend- } \\
\text { ation to } \\
\text { the Court }\end{array}$ & $\begin{array}{c}\text { Examiner } \\
\text { asked to } \\
\text { testify }\end{array}$ & $\begin{array}{l}\text { Action of } \\
\text { the Court }\end{array}$ \\
\hline 'Juan Garcia.... & 23 & Rape & Psychosis with & Commitment & Yes & Guilty \\
\hline Chas. B. Ogden... & 50 & $\begin{array}{l}\text { Failure to sup- } \\
\text { port minor } \\
\text { children }\end{array}$ & $\begin{array}{l}\text { Paranoia or } \\
\text { paranoid condition }\end{array}$ & Commitment & No & Committed \\
\hline Geo. G. Morrison. & 43 & Murder & $\begin{array}{l}\text { Without psychosis; } \\
\text { Mental deficieney }\end{array}$ & Not insane & Yes & Guilty \\
\hline $\begin{array}{l}\text { C. I. Graves..... } \\
\text { Tony R. Wilson .. } \\
\text { Blaine Evans.... }\end{array}$ & $\begin{array}{l}27 \\
25 \\
36\end{array}$ & $\begin{array}{l}\text { Murder } \\
\text { Forgery } \\
\text { Assault with } \\
\text { intent to rape }\end{array}$ & $\begin{array}{l}\text { Not insane } \\
\text { Not insane } \\
\text { Not insane }\end{array}$ & $\begin{array}{l}\text { Not insane } \\
\text { Not insane } \\
\text { Not insane }\end{array}$ & $\begin{array}{l}\text { Yes } \\
\text { Yes } \\
\text { No }\end{array}$ & $\begin{array}{l}\text { Guilty } \\
\text { Guilty } \\
\text { Guilty }\end{array}$ \\
\hline${ }^{2}$ Geo. K. Brown & 62 & $\begin{array}{l}\text { Passing worth- } \\
\text { less checks }\end{array}$ & $\begin{array}{l}\text { Manic depressive } \\
\text { psychosis; Manic } \\
\text { type }\end{array}$ & $\begin{array}{l}\text { Not insane; } \\
\text { Recovered } \\
\text { from psy- } \\
\text { chosis }\end{array}$ & No & $\begin{array}{l}\text { Case } \\
\text { dismissed }\end{array}$ \\
\hline $\begin{array}{l}\text { J. A. S. Backs. . } \\
\text { Sam Stockton.. }\end{array}$ & $\begin{array}{l}48 \\
35\end{array}$ & $\begin{array}{l}\text { Rape } \\
\text { Burglary; Grand } \\
\text { Larceny; Re- } \\
\text { ceiving Stolen } \\
\text { Goods }\end{array}$ & $\begin{array}{l}\text { Traumatic psychosis } \\
\text { Not insane }\end{array}$ & $\begin{array}{l}\text { Commitment } \\
\text { Not insane }\end{array}$ & $\begin{array}{l}\text { Yes } \\
\text { No }\end{array}$ & $\begin{array}{l}\text { Committed } \\
\text { Guilty }\end{array}$ \\
\hline $\begin{array}{l}\text { Alberto Sanchez. . } \\
\text { Nick Kassaras.... } \\
\text { Wm. Fields..... }\end{array}$ & $\begin{array}{l}24 \\
63 \\
42\end{array}$ & $\begin{array}{l}\text { Murder } \\
\text { Murder } \\
\text { Assault with } \\
\text { intent to kill }\end{array}$ & $\begin{array}{l}\text { Not insane } \\
\text { Not insane } \\
\text { Paranoia or para- } \\
\text { noid conditions }\end{array}$ & $\begin{array}{l}\text { Not insane } \\
\text { Not insane } \\
\text { Commitment }\end{array}$ & $\begin{array}{l}\text { Yes } \\
\text { Yes } \\
\text { Yes }\end{array}$ & $\begin{array}{l}\text { Guilty } \\
\text { Guilty } \\
\text { Committed }\end{array}$ \\
\hline
\end{tabular}

IOffense was against an infant; therefore the community was very bitter against the defendant and the plea of ineanity was

disregarded. 
Colorado State Hospital-(Continued)

\begin{tabular}{|c|c|c|c|c|c|c|}
\hline Name & Age & Offense & Diagnosis & $\begin{array}{l}\text { Recommend- } \\
\text { ation to } \\
\text { the Court }\end{array}$ & $\begin{array}{c}\text { Examiner } \\
\text { asked to } \\
\text { testify }\end{array}$ & $\begin{array}{l}\text { Action of } \\
\text { the Court }\end{array}$ \\
\hline Cal Thompson.. & 65 & Murder & Dementia praecox; & Commitment & Yes & Committed \\
\hline Mary Trongo . & 44 & Murder & Withoüt psychosis; & Not insane & Yes & Found \\
\hline Christina Volgin.. & 38 & Murder & Dementia praecox; & Commitment & Yes & Committed \\
\hline $\begin{array}{l}\text { Vance Shriver.... } \\
\text { 'James Foster.... }\end{array}$ & $\begin{array}{l}49 \\
49\end{array}$ & $\begin{array}{l}\text { Murder } \\
\text { Murder }\end{array}$ & $\begin{array}{l}\text { Not insane } \\
\text { Dementia praecox; }\end{array}$ & $\begin{array}{l}\text { Not insane } \\
\text { Commitment }\end{array}$ & $\begin{array}{l}\text { No } \\
\text { Yes }\end{array}$ & $\begin{array}{l}\text { Guilty } \\
\text { Not insane }\end{array}$ \\
\hline John Hrinek..... & 45 & Murder & Dementia praecox; & Commitment & Yes & Committed \\
\hline Jjoe Vonderheid.. & 56 & Burglary & $\begin{array}{l}\text { Without psychosis; } \\
\text { Mental deficiency; } \\
\text { Moron }\end{array}$ & $\begin{array}{l}\text { Supervision } \\
\text { by respon- } \\
\text { sible parties }\end{array}$ & No & Paroled \\
\hline $\begin{array}{l}\text { Mrs. Nina Palmer. } \\
\text { Tom Bell......... }\end{array}$ & $\begin{array}{l}49 \\
47\end{array}$ & $\begin{array}{l}\text { Forgery } \\
\text { Larceny as } \\
\text { bailee }\end{array}$ & $\begin{array}{l}\text { Not insane } \\
\text { General paralysis }\end{array}$ & $\begin{array}{l}\text { Not insane } \\
\text { Commitment }\end{array}$ & $\begin{array}{l}\text { No } \\
\text { No }\end{array}$ & $\stackrel{*}{*}$ Committed \\
\hline $\begin{array}{l}\text { Rudolph Bessetto. } \\
\text { John F. Taylor.... } \\
\text { Abel Sanchez..... } \\
\text { Walter Jones..... } \\
\text { Monred J. Neison. } \\
\text { Harvey Lee....... }\end{array}$ & $\begin{array}{l}22 \\
25 \\
47 \\
23 \\
26 \\
26\end{array}$ & $\begin{array}{l}\text { Murder } \\
\text { Murder } \\
\text { Murder } \\
\text { Murder } \\
\text { Murder } \\
\text { Larceny }\end{array}$ & $\begin{array}{l}\text { Not insane } \\
\text { Not insane } \\
\text { Not insane } \\
\text { Not insane } \\
\text { Not insane } \\
\text { Dementia praecox; }\end{array}$ & $\begin{array}{l}\text { Not insane } \\
\text { Not insane } \\
\text { Not insane } \\
\text { Not insane } \\
\text { Not insane } \\
\text { Commitment }\end{array}$ & $\begin{array}{l}\text { No } \\
\text { No } \\
\text { No } \\
\text { No } \\
\text { No } \\
\text { Yes }\end{array}$ & $\begin{array}{l}\text { Guilty } \\
* \\
\text { Guilty } \\
\text { Guilty } \\
\text { Committed }\end{array}$ \\
\hline $\begin{array}{l}\text { Hazel Howe Spicer } \\
\text { John J. Ross...... } \\
\text { oLester Gonce.... }\end{array}$ & $\begin{array}{l}41 \\
37 \\
51\end{array}$ & $\begin{array}{l}\text { Murder } \\
\text { Robbery } \\
\text { Murder }\end{array}$ & $\begin{array}{l}\text { Dementia praecox } \\
\text { Not insane } \\
\text { Not insane }\end{array}$ & $\begin{array}{l}\text { Commitment } \\
\text { Not insane } \\
\text { Not insane }\end{array}$ & $\begin{array}{l}\text { Yes } \\
\text { No } \\
\text { Yes }\end{array}$ & $\begin{array}{l}\text { Committed } \\
\text { Guilty } \\
\text { Found insane } \\
\text { by the iury }\end{array}$ \\
\hline${ }^{\prime}$ Frank Phillips... & 58 & Embezzlement & $\begin{array}{l}\text { Psychosis with cer- } \\
\text { ebral arterio- } \\
\text { sclerosis }\end{array}$ & Commitment & Yes & $\begin{array}{l}\text { Sentenced to } \\
\text { peni- } \\
\text { tentiary }\end{array}$ \\
\hline $\begin{array}{l}\text { Herbert Sewell ... } \\
\text { Delbert George... }\end{array}$ & $\begin{array}{l}19 \\
29\end{array}$ & $\begin{array}{l}\text { Murder } \\
\text { Murder }\end{array}$ & $\begin{array}{l}\text { Not insane } \\
\text { Without psychosis; } \\
\text { Mental deficiency; } \\
\text { Moron }\end{array}$ & $\begin{array}{l}\text { Not insane } \\
\text { Not insane }\end{array}$ & $\begin{array}{l}\text { No } \\
\text { No }\end{array}$ & $\begin{array}{l}\text { Guilty } \\
\text { Guilty }\end{array}$ \\
\hline $\begin{array}{l}\text { Charlie Graham ... } \\
\text { Wm. Unwin....... } \\
\text { Luther Hook..... } \\
\text { Ethel McDaniel. }\end{array}$ & $\begin{array}{l}41 \\
32 \\
39 \\
42\end{array}$ & $\begin{array}{l}\text { Murder } \\
\text { Rape } \\
\text { Larceny }\end{array}$ & $\begin{array}{l}\text { Dementia praecox } \\
\text { Without psychosis } \\
\text { Without psychosis } \\
\text { Without psychosis; } \\
\text { Mental deficiency; }\end{array}$ & $\begin{array}{l}\text { Commitment } \\
\text { Not insane } \\
\text { Not insane } \\
\text { Not insane }\end{array}$ & $\begin{array}{l}\text { Yes } \\
\text { Yes } \\
\text { No } \\
\text { No }\end{array}$ & $\begin{array}{l}\text { Committed } \\
\text { Guilty } \\
\end{array}$ \\
\hline C. Blaine Scott. . & 41 & Attempted mur- & $\begin{array}{l}\text { Moron } \\
\text { Traumatic psychosis; } \\
\text { Traumatic con- }\end{array}$ & Commitment & Yes & Committed \\
\hline Alex Nieberger... & 30 & Bestiality & $\begin{array}{l}\text { Psychosis with } \\
\text { Mental deficiency }\end{array}$ & Commitment & No & Committed \\
\hline $\begin{array}{l}\text { C. W. Robertson . } \\
\text { Arthur N. Carr... }\end{array}$ & $\begin{array}{l}35 \\
40\end{array}$ & $\begin{array}{l}\text { Confidence game } \\
\text { Assault with } \\
\text { deadly weapon } \\
\text { with intent to }\end{array}$ & $\begin{array}{l}\text { Not insane } \\
\text { Without psychosis; } \\
\text { Epilepsy; } \\
\text { idiopathic }\end{array}$ & $\begin{array}{l}\text { Not insane } \\
\text { Not insane }\end{array}$ & $\begin{array}{l}\text { No } \\
\text { Yes }\end{array}$ & Guilty \\
\hline Joe Brandon. & 35 & & $\begin{array}{l}\text { Dementia praecox: } \\
\text { Hebephrenic,type }\end{array}$ & Commitment & * & Committed \\
\hline
\end{tabular}

Information is not in the records.

Patient killed husband's paramour and had the sympathy of the entire community. Judge did not commit patient after jury found her ingane.

Patient also at Colorado Psychopathic Hospital. Crime so brutal and patient so clear mentally jury found him sane and he was hanged.

Patient was under supervision on parole from court in community but was committed two years later.

Patient killed a brutal deputy sheriff. It was common gossip the community was benefitted by the act.

Patient began peculation 2 number of years prior to onset of psychosis. Received active treatment while in hoipital so that at time of trial was practically normal mentally. 


\section{Experience in OTHER STates}

The main significance of the Colorado statistics is that they are fairly typical of the results in other states having similar laws. In the percentage of cases reported by the hospitals as insane, Colorado's 39 per cent is to be compared with $4 \mathrm{I} 1 / 2$ per cent in Vermont, and $251 / 3$ per cent in Ohio. For a more complete record of the diagnoses made by the hospitals, we may take the record of the Augusta State Hospital in Maine, where during the period of twenty' years from February 14, 19r4, to March 22, 1934, 189 defendants were committed and examined. The hospital's diagnoses in these 189 cases totalled as follows:

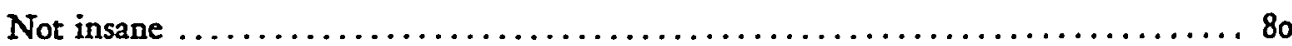

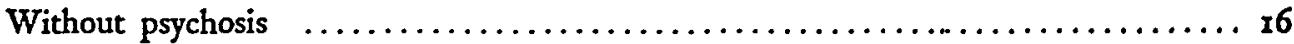

Psychopathic personality-not insane $\ldots \ldots \ldots \ldots \ldots \ldots \ldots \ldots \ldots \ldots \ldots \ldots \ldots, \mathbf{x}$

Constitutional psychopath - not insane $\ldots \ldots \ldots \ldots \ldots \ldots \ldots \ldots \ldots \ldots \ldots \ldots \ldots \ldots$ r

Constitutional inferiority - not insane $\ldots \ldots \ldots \ldots \ldots \ldots \ldots \ldots \ldots \ldots \ldots \ldots, 4$

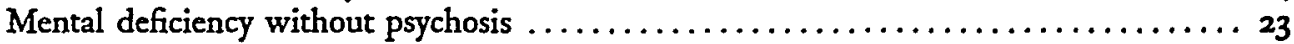

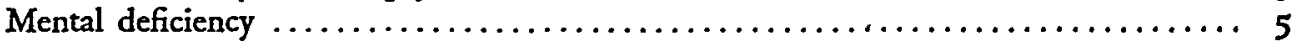

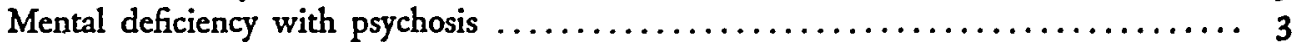

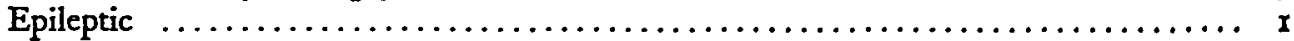

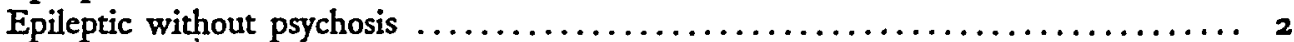

Epileptic with psychosis $\ldots \ldots \ldots \ldots \ldots \ldots \ldots \ldots \ldots \ldots \ldots \ldots \ldots \ldots \ldots \ldots \ldots \ldots \ldots \ldots$, I

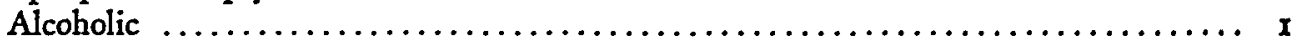

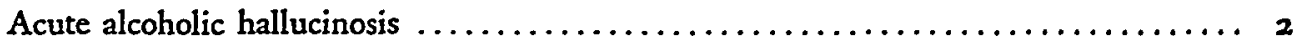

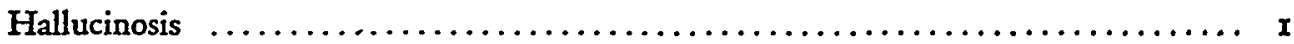

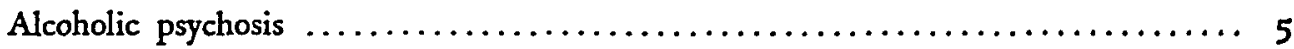

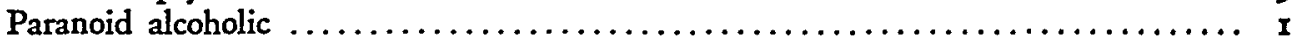

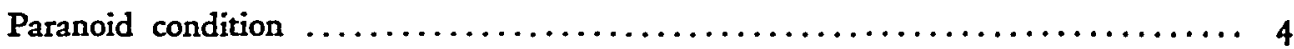

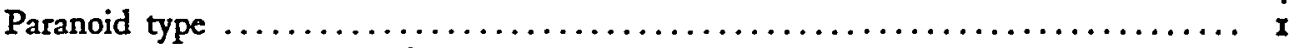

Dementia praecox-paranoid $\ldots \ldots \ldots \ldots \ldots \ldots \ldots \ldots \ldots \ldots \ldots \ldots \ldots \ldots \ldots, \quad 3$

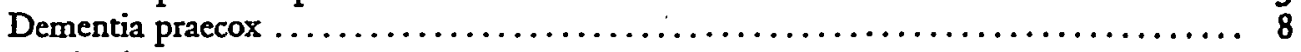

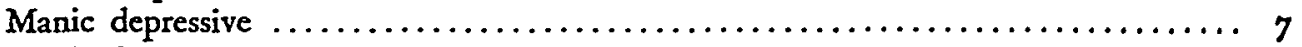

Manic depressive-Manic $\ldots \ldots \ldots \ldots \ldots \ldots \ldots \ldots \ldots \ldots \ldots \ldots \ldots \ldots \ldots \ldots \ldots \ldots, \quad 5$

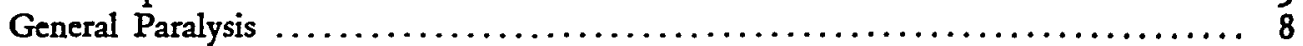

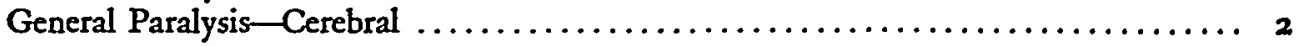

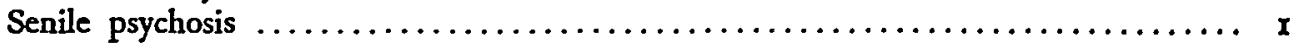

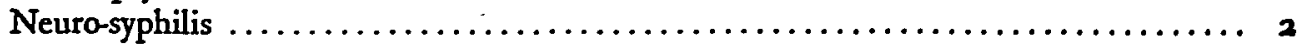

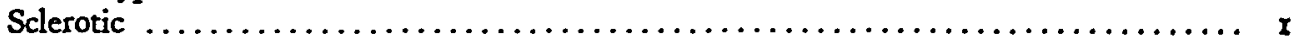

The willingness of both counsel and juries to accept the findings of the hospitals, and the consequent elimination of controversy over the question of sanity or insanity, is the outstanding accomplishment of the laws of all these states. Thus, under the Maine law, Superintendent Forrest C. Tyson of the Augusta State Hospital has informed the writer that during the twenty-one years of his service at that institution, there have been 202 cases committed for observation, 27 of them persons indicted for murder. In only two cases have attorneys for the defense refused to abide by the hospital's finding. In those two cases-and in no others-other psychiatrists were 
retained to testify contrary to the hospital's report. In neither case, however, did the defense succeed, both defendants being found guilty and sentenced. The subsequent clinical records of the two have borne out the hospital's original diagnoses. Under the same law, Superintendent Carl J. Hedin of the Bangor State Hospital reports that during the sixteen years he has held that position, $5^{8}$ persons have been sent to that institution for observation. In 55 of these cases, the jury accepted the hospital's finding. Other expert testimony is rarely introduced.

For the benefit of those who fear the hospital authorities will be too prone to fine all persons charged with crime to be insane, it may be interesting to notice that in the eighty-eight years that the Maine law has been in operation, there have been only eight murder cases in which the defendants were found not guilty by reason of insanity.

The Vermont law is almost identical in wording with that of Maine. During the past fifteen years, 90 cases have been committed to the Vermont State Hospital under this law. Of these, 52 have been reported back as not insane, 37 as insane, and one as undiagnosed (a non-resident who was transferred back to her home state). In only one case was the hospital opposed by an alienist retained by the defense, and there the jury, accepting the testimony of the hospital rather than that of the defense, found the defendant guilty. Indeed, in Vermont, the confidence of all concerned in the hospital's findings seems to be such that its finding, reported to the prosecutor and to counsel for the defense, is usually sufficient; in only fourteen of the 90 cases diagnosed did a member of the hospital staff testify at the trial. In the others, the insanity defense was disposed of without any testimony on the subject. If the defendant is reported insane by the hospital, the court commits him to the hospital; if the hospital finds him sane, he is ordered to stand trial, and, with the single exception mentioned, counsel has dropped the insanity defense.

Under the Ohio law, enacted in 1929 , $7 x$ persons have been committed to the Lima State Hospital for the criminal insane for observation. Of these, 18 , or slightly over 25 per cent, were found insane. Dr. R. E. Bushong, superintendent of the hospital, states that in homicide or other serious cases, where the defendant has financial resources to employ high-priced lawyers, an attempt is sometimes made to prove the defendant insane even when the hospital has found him sane, but that he knows of no case in which the jury has acquitted a defendant under such circumstances.

In some of the larger cities, psychopathic clinics are conducted in connection with the municipal courts, with facilities for holding patients for observation. Milwaukee County, for example, has a Mental Hygiene Clinic which has been able to make accurate examinations of the patients referred to it. The Wisconsin legislature has been contemplating establishing a Diagnostic Center, to which all cases of suspected mental abnormalities would be sent, instead of to the various state institutions. After a period of residence at this center, the patient would be transferred to the institution which it was felt was best suited to care for him. This would eliminate in Wiscon- 
sin the practice now current not oilly there but in practically all states, of making commitments to some specific institution, without much knowledge on the part of the committing court as to whether that institution is best suited for the individual's needs or not.

\section{An Aiternative Solution: Appointment of Experts by the Court}

A provision which might be considered as a substitute for commitment to a hospital is one permitting the court to appoint experts to examine the defendant and report. At least five states now have statutes permitting such appointments when the issue of criminal responsibility is involved; ${ }^{12}$ eight when the question is the defendant's present capacity to stand trial, ${ }^{13}$ and three for either or both purposes..$^{14}$

The Model Code of Criminal Procedure, promulgated by the American Law Institute in 1930, includes such a provision. ${ }^{15}$ This seems, however, to add nothing

${ }^{22}$ Cal. Penal Code (Deering, r931) §ro27; see also Cax. Code Crv. Proc. (Deering, r93r); \$r871; Colo. Laws I927, c. 90, \$2; Ind. Acts I927, c. I02; Ind. Ans. Stat. (Baldwin, I934) \$2216; R. I. GEN. LAws (I923) \$5002; VT. Gen. LAws (1917) \$2620. See also lowa Acts 1933-34, Extra sess., c. 133, p. 257 (when a party to any legal action, suit or other judicial proceedings pleads his own mental incapacity, any other interested party may apply to have such person produced for examination as to mental capacity by physicians chosen by the applicant.) Inquiry of the Attorney General of lowa has failed to elicit any information as to whether this statute is to be construed to apply to criminal cases.

${ }^{2 s}$ ALA. Code (I928) $\$ 4577$ (judge must call "a respectable physician"); Conn. Pub. Acts I931, p. 269 (investigation by two or three "reputable, disinterested and qualified physicians" appointed by the judge); IND. ANN. STAT. (Baldwin, 1934) $\$ 2216$ (judge shall appoint "two competent disinterested physicians" who shall examine defendant and testify at the hearing); KY. STAT. (Carroll, 1930) \$5216aa-68. 2r6aa-74 (similar to Indiana); Mo. Anv. Code (Bagby, 1924) art. 59, \$8; Mrch. Comp. Laws (1929) \$r724I, as amended, Mich. Pub. Acts I93I, No. 3I7, p. 53I; PA. Stat. (Supp. 1928) \$14726a-308 (court may order inquiry by two "qualified physicians," or by a commission of two "qualified physicians" and one lawyer); VA. CoDE (Michie, 1930) 54909.

${ }^{16}$ La. Acts 1932, No. 136; N. Y. CODE CRrM. PROC. $\$ \$ 658,659$ (on plea of not guilty by reason of insanity, court may appoint a commission of not more than three "disinterested persons" to examine defendant and report to the court). It has been held this report must cover his sanity both at the time of the act charged, and at the time of the investigation. People v. Whitman, I49 Misc. 159, 266 N. Y. Supp. 844 (I933). × See also N. Y. Consol. Laws (Cahill, r930) c. 3r, 53I; N. Y. Code Crim. Proc. 5836, as amended, N. Y. Laws 1933, c. 564 ; Wrs. Stat. (1933) $\$ 357.12$ (3).

${ }^{15}$ Section 307. Examination of defendant's mental condition to determine whether he shall be tried. (I) If before or during the trial the court has reasonable groind to believe that the defendant, against whom an indictment has been found or information filed, is insane or mentally defective to the extent that he is unable to understand the proceedings against hin or to assist in his defense, the court shall immediately fix a time for a hearing to determine the defendant's mental condition. The court may appoint two disinterested qualified experts to examine the defendant with regard to his present mental condition and to testify at the hearing. Other evidence regarding the defendant's mental condition may be introduced at the hearing by either party.

(2) If the court, after the hearing, decides that the defendant is able to understand the proceedings and to assist in his defense it shall proceed with the trial. If, however, it decides that the defendant through insanity or mental deficiency is not able to understand the proceedings or to assist in his defense it shall take proper steps to have the defendant committed to the proper institution. If thereafter the proper officer of such institution is of the opinion that the defendant is able to understand the proceedings and to assist in his defense, he shall report this fact to the court which conducted the hearing. If the officer so reports, the court shall fix a time for a hearing to determine whether the defendant is able to understand the proceedings and to assist in his defense. This hearing shall be conducted in all respects like the original hearing to determine defendant's mental condition. If after this hearing the court decides that the defendant is able to understand the groceedings against him and to assist in his defense it shall 
to the common law. Even without the aid of such a statute, trial courts have at times appointed expert witnesses to examine the accused as to his mental condition, ${ }^{16}$ and this practice has been approved. ${ }^{17}$ It is true that the Michigan Supreme Court, by a strange process of reasoning, has held that the courts do not have this power, even where a statute expressly undertook to confer such power, ${ }^{18}$ and this reasoning has been followed by the Illinois court. ${ }^{18}$

It is probable, however, that the courts of other states will not become infected with this dykastophobia, as Dean Wigmore called it, but will continue to permit trial courts to call in expert witnesses where proper. While, as we have said, this seems to have been a common law power of the courts, it is probably true that the judges will be more likely to make use of the power where it is expressly provided for by statute. Such a provision does have the virtue of introducing scientific testimony regarding the defendant's mental condition other than the paid and partisan testimony of the experts brought in by the parties. California and Indiana have gone somewhat further than the Model Code, by making the appointment of such experts mandatory instead of merely permissive. ${ }^{20}$

\section{Superior Merits of Hospital Commitment}

Beyond this, however, there is not much that can be said for such a procedure. It is definitely inferior to the procedure for commitment to a state hospital. It is not a satisfactory method to ask psychiatrists to make an important examination in a jail or prison. Such an examination does not compare with the type of examination made in any modern hospital, and is not fair either to the prisoner, or the state, or to the examiner as a scientific man. Such an examination should be supplemented by prolonged observation in a different and more natural environment. In I928, a

proceed with the trial. If, however, it decides that the defendant is still not able to understand the proceedings against him or to assist in his defense it shall recommit him to the proper institution.

Section 308. Appointment of expert witnesses by cout. Whenever on a prosecution by indictment or information the existence of insanity or mental defect on the part of the defendant at the time of the alleged commission of the offense charged becomes an issue in the cause, the court may appoint one or more disinterested qualified experts, not exceeding three, to examine the defendant. If the court does so, the clerk shall notify the prosecuting attorney and counsel for the defendant of such appointment and shall give the names and addresses of the experts so appointed. If the defendant is at large on bail, the court in its discretion may commit him to custody pending the examination of such experts. The appointment of experts by the court shall not preclude the State [Commonwealth or People] or defendant from calling expert witnesses to testify at the trial and in case the defendant is committed to custody by the court they shall be permitted to have free access to the defendant for purposes of examination or observation. The experts appointed by the court shall be summoned to testify at the trial and shall be examined by the court and may be examined by counsel for the State [Commonwealth or People] and the defendant.

${ }^{10}$ State v. Cockriel, 314 Mo. 699, 285 S. W. 440 (1926); State v. Petty, 32 Nev. 384, I08 Pac. 934 (I9I0); State v. Paine, 49 La. Ann. Io92, 22 So. 316 (I897); State v. Genna, I63 La. 701 , II2 So. 655 (I927).

${ }^{17}$ People v. Linton, I02 Cal. App. 608, 283 Pac. 389 (1929); State v. Genna, supra note x6; State v. Horne, 171 N. C. 787,88 S. E. 433 (r916).

${ }^{23}$ People v. Dickerson, I64 Mich. I48, I29 N. W. I99 (I9Io).

${ }^{10}$ People v. Scott, 326 Ill. 327,157 N. E. 247 (1927).

${ }^{\infty}$ Statutes cited, note 12 , supra. 
committee of the American Psychiatric Association recommended that expert witnesses should be given "opportunity for thorough psychiatric examination using such aids as psychiatrists customarily use in practice, clinics, hospitals, etc., with obligatory written reports and remuneration from public funds."21

Secondly, all too often, the "experts" appointed under such statutes are such in name only. Any practicing physician can qualify as an "expert" on insanity, even though he never studied psychiatry or handled a mental case in his life. True, some statutes as well as the Model Code make a gesture toward limiting the field by referring to "disinterested qualified experts" but there is no definition of what is required to "qualify" one as an expert. ${ }^{22}$ All we can say for such provisions is that they do bring into the case impartial experts, not paid to support either side of the case; but there is no guaranty that such witnesses will be any better qualified to diagnose the case than those retained by the parties, nor is the opportunity for scientific diagnosis improved.

If it be suggested that commitment may be more expensive, the writer ventures to guess that the reverse is more likely to be the case. The cost of maintaining one more patient in an existing hospital for thirty days is not great; so far as salaries are concerned, the added cost is nil, unless the number of such cases grows so large that it is necessary to add to the hospital staff. Even in this case, it would still probably be cheaper to add another member to the hospital staff, and to pay the added annual salary of one more doctor, rather than to hire from one to three experts to examine each of these cases, with fees ranging from $\$ 25$ to $\$ 100$ per day per expert.

The superior merits of the commitment procedure is demonstrated by the experience of states where both procedures are available. This is true in Colorado and Vermont. The Colorado law, as we have said, makes commitment mandatory, and the appointment of experts by the court only discretionary, so there is, perhaps, no fair basis for comparison. However, it is significant that commitment to the hospital has been found sufficient. It is very rare for the trial court also to appoint experts to examine the defendant. In Vermont, both provisions are discretionary. Section 2620 of the Vermont General Laws authorizes a superior judge or the attorney general, to prevent a failure of justice, to order an examination made by the experts. The order is made only on the petition of the state's attorney, stating the facts requiring

Menninger, supra note 7 , at 376 .

"Some of the statutes do require that the "experts" actually be specialists in mental diseases, or at least have had some actual experience in a hospital for mental diseases. CAI. Penal. Code (Decring 193I) $\$ 1027$ (court must appoint two or three "alienists, at least one of whom must be from the medical staffs of the state hospitals"); La. Acts I932, No. I36 ("By qualified experts in mental diseases is meant a physician expert in insanity who shall have been duly licensed in this State or another State and shall have been graduated from a legally chartered medical school or college, and who shall have been in the actual practice of medicine for three years last preceding the acceptance of appointment for examination and who shall have had at least one year's experience in a hospital for mental diseases actually in contact with and examining insane persons or who shall have practiced as a specialist in nervous and mental diseases for a period of at least three years"); N. Y. Code Crims. Proc., \$836, as amended, N. Y. Laws 1933, c. 564 (court may call two physicians . . . at least one of whom shall be a qualified psychiatrist as provided by law"). See Strauss, The Qualification of Psychiatrists as Experts, infra, p. 46r. 
the order, and naming the experts by whom examination is to be made. Section 2602 authorizes the trial judge, where a plea of insanity is made, or the trial judge is satisfied it will be made, to order the defendant into the care of the superintendent of the Vermont State Hospital for detention and observation "that the truth or falsity of the plea may be ascertained." In practice, the latter provision is the one used; there seems to be no instance in which a court appointed experts to examine a defendant's mental condition under section 2620 .

It therefore seems unfortunate that the reporters who drafted the Model Code merely provided in sections $3 I 7$ and $3^{I 8}$ for appointment of experts. It should be pointed out that as a footnote to these sections, the reporters appended alternative provisions recommended for "states where there is a public institution or institutions for investigating the mental condition of persons, to which defendants can be conveniently committed for examination," which do not change the wording of these sections except to give the court the choice either to appoint experts to examine the defendant, or to "commit the defendant to the proper institution for observation and examination." Just why this much more useful provision should be included only in small type as a substitute, instead of as the primary recommendation, is not clear. The only reason seems to have been that not all states have institutions to which defendants could be committed for observation and examination. It is submitted that by far the majority of states do have such facilities, and that those which do not are probably also not well supplied with psychiatrists who could be deemed "qualified experts," so that even such states are probably in no better position to use the one provision than the other.

The most unfortunate effect of the typography adopted by the framers of the Code is that the printing of the less useful recommendation in big bold-faced letters and the other in much smaller type, as a substitute, may seem to imply that the former is its first choice. Such a result would make the Code an obstacle to progress rather than a help. And this seems to be the implication which some legislatures have been given. Louisiana, for example, in 1932 adopted a law which follows the wording of the Model Code (except that the Louisiana law corrects an obvious defect by defining "qualified experts"). ${ }^{23}$ Louisiana has two state hospitals to which the criminal insane might be committed for observation, and its legislature had already shown a willingness to experiment with the problem. ${ }^{24}$ Furthermore, its supreme court had already held that the trial courts have power to appoint experts in these cases, without the aid of a statute. ${ }^{25}$ Why then did Louisiana adopt the ineffectual statute it did? We can only guess, for the legislative journals reveal no reason, and neither the Attorney General's office nor the superintendents of the two state hospitals know what the reason was. ${ }^{28}$ However, having decided to make the change,

- La. Acts 1932, No. 136 .

${ }^{24}$ Sec La. Acts I928, No. I7; LA. CODE CRIM. Proc. (Dart, I928) arts. 267-273.

${ }^{20}$ State v. Genna, 163 La. 701, 112 So. 655 (1927).

Dr. S. T. Phillips of the Central Louisiana State Hospital suggests the possible reason that a large 
it is clear that the legislators turned to the Model Code for their new law, and adopted what evidently seemed to be that Code's primary recommendation.

\section{Details of Draftsmanship}

In drafting statutes of the type which the Model Code actually recommends for the majority of states, one or two details may be considered. The substitute for section $3^{18}$ requires that the hospital authorities "prepare a written report regarding the mental condition of the defendant insofar as this indicates what was his mental condition at the time of the alleged offense. Such officer shall be summoned as a witness at the trial and may be examined by the judge or by either party."

It may be questioned whether this language is not too neat and complete. A less specific, more loosely drawn statute might permit a good deal of informality such as is practiced in most of the states now having such provisions. Thus, for example, in Maine no written reports are given out, and Superintendent Tyson of the Augusta State Hospital is of the opinion that this is the better practice; that when such reports are made public, the attorneys have too, much opportunity to pick minute flaws in them, build up hypothetical issues, and generally fine-comb the report for legalistic, as distinguished from scientific, discrepancies; furthermore, that such reports are "hot stuff" for the newspapers. Whether this point of view is correct or not, it would seem wiser to permit the courts and the hospital to work this out as a matter of custom, rather than embody a definite rule in the statute.

Again, the Model Code definitely says the hospital officer shall be summoned as a witness at the trial. In Maine, in minor cases at least, the court disposes of the case upon the hospital's report, without requiring any member of the staff to testify at the trial, and in Ohio and Vermont, it has been found unnecessary to call the hospital officials in the great majority of cases. In 76 cases out of the 90 which have arisen under the Vermont law, the hospital's report to the defense and to the prosecutor has been found sufficient to dispose of the insanity issue. At the Colorado State Hospital, a member of the staff has been asked to testify in only twenty-one out of forty-one cases. Here again, it would seem wiser not to make the statutory rule too rigid. To provide that the hospital officers "may" be called as witnesses would seem to cover the situation, without imposing unnecessary formality where it can be avoided.

\section{MORE Radical InNOvations}

A word of warning may be in order to legislative draftsmen who may be inclined to carry this reform further. States which have departed too far from the accepted

number of defendants were pleading insanity merely as a last means of escape, and sitting on commissions to examine such cases consumed a large part of the time of the heads of the institutions. Dr. Jackson J. Ayo of the East Louisiana State Hospital suggests that the change was made to permit the examination to be made in the local parish, and thus save expense. The Attorney General's Office points out that the exclusion of the state from ever prosecuting the defendant after the commission found him insane may have been considered unsatisfactory. 
modes of procedure, especially in attempting to take the question of the defendant's mental condition entirely away from the jury, and place it into the hands of a body of experts, have met constitutional difficulties. Louisiana presents a case in point. In 1928 , that state adopted a very ingenious procedure, under which a defendant interposing a plea of insanity was first examined by a commission, made up of the superintendents of the two state insane hospitals and the coroner of the parish. If this commission found him sane, either presently or at the time of the offense, he was committed to the criminal ward of a hospital without further ado. A finding that the defendant was insane at the time of the act charged precluded the state from ever bringing him to trial on the indictment, thus saving the expense and trouble of a criminal trial. Even if the commission found him presently sane, though insane at the time of the act, he could still be committed, in order that by observation over a period of time, it might be determined whether he could with reasonable safety be returned to society. If the commission found him sane, he still was given a judicial hearing on the issue, as in other cases. ${ }^{27}$ If found sane, he was then tried upon the other issues in the case. If found insane, he was forthwith committed to the criminal ward of a state hospital. This procedure was held constitutional. ${ }^{28}$

Soon after its enactment, however, a radical revision of this procedure was attempted by a law which made the decision of the commission conclusive in all cases, whether its finding was that the defendant was sane or insane, and permitted no judicial hearing on the issue of insanity whatsoever, either with or without a jury. This was declared unconstitutional. The defendant has a right to a jury trial on all the issues in the case, and his mental capacity to commit the crime is one of the essential elements of the crime upon which he is entitled to a jury verdict. ${ }^{29}$

Since that time, the Louisiana law has been completely repealed, substituting therefore the provision found in section $3^{I} 8$ of the Model Code, authorizing the trial court in such cases to appoint from one to three experts to examine the defendant where the defense of insanity is raised..$^{30}$

The 1928 law seems to have been an interesting one. It had the great merit of frankly accepting, so far as the state is concerned, the finding of the state's own experts. Where the superintendents of the two hospitals and the coroner of the parish, all state officials, agree that a defendant is mentally irresponsible, it seems both humane and economical to provide that such finding shall bind the state's prosecutor

\footnotetext{
${ }^{27}$ As a matter of fact, however, the Louisiana law had the same practical result as found in other states having laws providing for official examination before trial: counsel for the defense invariably accepted the finding of the commission. Superintendent S. J. Phillips of the Central Louisiana -State Hospital informs the writer that during the four years the law was in effect, he knows of no instance in which, after the commission had reported the defendant "sane," counsel tried to contest that issue before a jury.

${ }_{23}$ State v. Burris, 169 La. 520, 125 So. 580 (1929); State v. Toon, 172 La. 631 , 135 So. 7 (1931); State v. Harper, 172 La. 1067, $\times 36$ So. 54 (193I).

${ }^{2}$ State v. Lange, 168 La. 958 , 123 So. 639,67 A. L. R. 1447 (1929). See also State v. Strasburg, 60 Wash. 106, I10 Pac. I020 (x910); Sinclair v. State, I6r Miss. 142, I32 So. 581 (1931).

${ }^{50}$ La. Acts 1932, No. 136 .
} 
and shall settle the question of mental condition. At the same time, the act did not preclude the defense from taking the issue to the jury, if the commission's finding was adverse to the defendant's contention of insanity.

It is unfortunate that this sensible provision was dropped in favor of the much less effective provision of the Model Code. Other states might well consider its adoption, especially when incorporated into a statute providing for observation in a state hospital. The writer ventures to suggest a possible wording of such a statute:

\section{Commitment to Institution for Examination}

(r) Whenever on any criminal prosecution the existence of insanity or mental defect on the part of the defendant either at the time of the alleged commission of the offense charged, or at the time of the criminal proceedings becomes an issue in the cause, 31 or the court has reasonable ground to believe that it may become an issue in the cause, the court may commit the defendant to [the proper institution] for a period not to exceed thirty days for observation and examination, and direct that the chief medical officer of such institution report to the court regarding the mental condition of the defendant both as of the time of the alleged offense and presently.

(2) If said report be that the defendant was insane and irresponsible at the time of the commission of the offense, the court may dismiss the charge against him, and forthwith commit him to [the proper institution for the criminal insane], there to remain until discharged in due course of law.

(3) If 'said report be that the defendant was, at the time of the commission of the offense charged, not mentally irresponsible, but that he is presently too insane to understand the proceedings against him or to assist in his defense, the court may forthwith commit him to [the proper institution for the criminal insane]. If thereafter the proper officer of such institution is of the opinion that the defendant is able to understand the proceedings and to assist in his defense, he shall report this fact to the court which conducted the hearing, which shall thereupon proceed with the trial.

(4) If said report be that the accused was sane and responsible at the time of the commission of the offense, and is now mentally able to understand the proceedings against him and to assist in his defense, the trial shall be proceeded with as in other cases. The officer of the institution making the report may be summoned as a witness at the trial and may be examined by the judge or by either party. The action of the court in committing the defendant for examination shall not preclude the State [Commonwealth or People] or defendant from calling expert witnesses to testify art the trial, and they shall be permitted to have free access to the defendant for purposes of observation and examination while the defendant is in custody or in an institution.

Such a statute would accomplish directly and simply what is now being accomplished at considerably more expense and trouble in the four states having provision for hospital commitment but where the requirement of trial is preserved even though the examiners' finding is that the defendant was insane at the time of the commission of the offense. As we have seen, the jury in these states almost invariably

${ }^{\text {s1 }}$ In eight states, the issue of insanity can be raised only on a special plea of "not guilty by reason of insanity." The writer has not included such a provision in this proposed statute in order not to become involved in the question of the desirability of requiring such a special plea, a matter collateral to our inquiry. If such a special plea should be required, this statute could read, "Whenever such a plea of insanity is made, the court may commit the defendant . . ." etc. 
accepts the finding of the hospital authorities. Also, trial judges have the power, if they wish to exercise it, of instructing the jury to return a verdict in accord with the hospital's finding. Thus, in Maine, upon a report and testimony by the hospital officer that the defendant was insane and irresponsible at the time of the offense charged, some of the judges order the prosecution to put on enough evidence to establish the facts of the crime, and then instruct the jury to bring in a verdict of not guilty by reason of insanity. While this does not eliminate the expense and trouble of a trial, it does reduce the trial to little more than a pro forma proceeding.

In Vermont, upon report by the hospital that the defendant is mentally irresponsible, the case is sometimes nolle prossed and the defendant committed to the hospital through the probate court as any ordinary patient. In a few cases, upon receipt of such a report, the State's Attorney has simply taken no action, but has allowed the defendant to remain in the hospital under the original commitment (such commitment, under the Vermont law, being not for any limited period, but "until further order of the court").

But these are round-about means of avoiding the useless formality of a criminal trial, and are not likely to be employed except occasionally by courageous judges. A statute of the sort proposed above would expressly authorize the courts to dismiss the criminal charge and commit the defendant to a hospital in all cases where the hospital authorities report him to be mentally irresponsible. Of course, if the hospital finds him sane, he is still entitled as a constitutional right to go to the jury on his contention that he is mentally irresponsible. But where he contends that he is not guilty by reason of insanity, and the state's own hospital authorities agree with him, why should not the state accept that finding, dismiss the criminal proceedings and commit him as insane?

Such a provision would add to the advantages of the statutes of the four states mentioned the further virtue of economy. An important criminal trial may cost the state several thousand dollars. The elimination of only one such trial each year would probably cover the cost of commitment for observation of all defendants whose sanity is in question. 